\title{
Peningkatan Kedisiplinan Siswa Masuk Kelas melalui Layanan Konseling Kelompok dengan Pendekatan Behavioral
}

\author{
Lutiyem
}

SMP Negeri 1 Talang Kabupaten Tegal

\begin{abstract}
Abstrak
Permasalahan dalam penelitian tindakan bimbingan ini adalah rendahnya tingkat kedisiplinan siswa masuk kelas pada siswa kelas VIIIA SMP Negeri 1 Talang tahun Pelajaran 2019/2020. Untuk mengatasi masalah tersebut, peneliti melakukan penelitian tindakan kelas selama 2 siklus yang setiap siklusnya dilaksanakan dalam 2 kali pertemuan dengan menggunakan layanan Konseling kelompok dengan pendekatan behavioral. Dari hasil pengamatan menunjukkan adanya peningkatan kedisiplinan siswa masuk kelas datang tepat waktu pada prasiklus terlambat 13 siswa (40,63\%), bolos 6 siswa (18,75\%), alpa 10 siswa 31,25\%). Setelah diadakan tindakan pada siklus 1, terlambat 6 siswa (18,75\%), bolos 3 siswa $(9,36 \%)$,alpa 6 siswa $(24 \%)$. Pada siklus 2 mengalami peningkatan yang signifikan terlambat 3 siswa $(9,36 \%)$, bolos ( $0 \%$ ), alpa 2 siswa $(5,8 \%)$. Hal ini menunjukkan adanya peningkatan kedisiplinan siswa masuk kelas/sekolah. Berdasarkan hasil penelitian tersebut, maka dapat disimpulkan bahwa model Konseling kelompok dengan pendekatan behavioral terbukti dapat meningkatkan kedisiplinan siswa masuk kelas pada siswa VIIIA semester 2 SMP Negeri 1 Talang Tahun Pelajaran 2019/2020.

Kata Kunci : Disiplin, Konseling Kelompok, Pendekatan Behavioral
\end{abstract}

\begin{abstract}
The problem in this guidance action research is the low level of discipline of students entering the classroom in class VIIIA students of SMP Negeri 1 Talang in the 2019/2020 academic year. To solve this problem, the researcher conducted a class action research for 2 cycles, each cycle carried out in 2 meetings using group counseling services with a behavioral approach. From the observations, it showed that there was an increase in the discipline of students entering the class who came on time in the late pre-cycle 13 students (40.63\%), 6 students skipped (18.75\%), 10 students missed $31.25 \%)$. After the action was held in cycle 1, 6 students were late (18.75\%), 3 students skipped (9.36\%), 6 students missed (24\%). In cycle 2 there was a significant increase in being late for 3 students $(9.36 \%)$, skipping classes $(0 \%)$, and missing 2 students (5.8\%). This shows an increase in the discipline of students entering class / school. Based on the results of this study, it can be concluded that the group counseling model with a behavioral approach has been proven to improve student discipline in class in second semester students of SMP Negeri 1 Talang in the 2019/2020 academic year. Keywords: Discipline, Group Counseling, Behavioral Approach
\end{abstract}




\section{PENDAHULUAN}

Pendidikan di sekolah tidak hanya sekedar menyampaikan bahan ajar kepada peserta didik, akan tetapi lebih dari itu yaitu upaya menanamkan nilai-nilai yang berharga bagi kepentingan hidup bersama. Salah satu nilai yang harus ditanamkan lewat aktifitas pendidikan adalah disiplin. Pada umumnya di sekolah masalah disiplin dikaitkan dengan kewajiban yang harus ditaati oleh siswa selama mengikuti aktifitas di sekolah. Salah satu kewajiban yang dimaksud adalah mentaati tata tertib sekolah diantaranya adalah disiplin masuk kelas.

Menurut Loso (2007) mendifinisikan disiplin adalah suatu sikap yang diwujudkan dengan perbuatan dalam melaksanakan tugas atau peraturan sesuai dengan waktu dan ketentuan yang ditetapkan. Disiplin juga mendorong, membimbing, dan membantu anak agar memperolehperasaan puas karena kesetiaan dan kepatuhannya dan mengajarkan kepada anak berpikir secara teratur.

Kedisiplin merupakan sikap, tingkah laku dan perbuatan yang sesuai dengan peraturan sekolah baik yang tertulis maupun yang tidak tertulis. Peraturan yang dimaksud termasuk absensi, terlambat masuk dan cepat pulang/ bolos. Menurut Conny Setiawan (2009) Kedisiplin itu tumbuh dari kebutuhan untuk menjaga keseimbangan antara kecedenderungan dan keinginan individu untuk berbuat sesuai dan dapat di peroleh atau kerena kondisi tertentu dengan pembatasan peraturan yang diperlukan terhadap dirinya dan lingkungan tempat ia hidup. Penerapan disiplin dalam lingkungan pendidikan adalah menerapkan sikap siswa yang tunduk dan patuh terhadap aturan yang berlaku dalam lembaga pendidikan tersebut, dalam peroses penerapan disiplin ini sangat erat kaitannya dengan tata tertib sekolah, penerapan disiplin dapat dilihat dan dinilai melalui tata tertib yang berlaku dilebaga pendidikan.

Kedisiplinan masuk kelas perlu diadakan dengan tujuan agar dalam proses pembelajaran dapat berjalan lancar. Menurut Schaefer (dalam Yulia Rintiyastini, 2006) membagi tujuan penanaman disiplin menjadi dua, yaitu tujuan jangka pendek dan tujuan jangka panjang. Tujuan jangka pendek dari penanaman disiplin adalah untuk membuat seseorang terlatih dan terkontrol. Misalnya memberi tahu bentuk tingkah laku yang pantas dan tidak pantas. Contoh konkrit adalah siswa tidak datang terlambat, tidak sering alpa, tidak membolos, mematuhi perintah orang tua atau guru dan sebagainya.

Adapun tata tertib yang berlaku di SMP N 1 Talang Kabupeten tegal antara lain sebagai berikut: Siswa jam 07.00 WIB tepat harus sudah berada di kelas untuk mengikuti pelajaran sampai pukul 13.10 WIB, bagi siswa yang datang terlambat/ bolos pelajaran dikenai sanksi. Begitu pula kehadiran di sekolah sangatlah penting. Kalau siswa sering tidak ikut dalam proses pembelajaran tanpa keterangan/ alfa, ijin sakit, ijin kepentingan lain tentunya akan tertinggal materi pelajaran. Sedangkan siswa yang alfa akan terkena sanksi peraturan 90\% (sembilan puluh prosen) wajib masuk sekolah, ikut dalam proses kegiatan belajar mengajar dan melaksanakan apa yang ditugaskan oleh guru masing-masing.

Kenyataan yang terjadi di SMP N 1 Talang Semester 2 Tahun Pelajaran 2019/2020 masih adanya siswa yang terlambat, tidak masuk tanpa keterangan, ijin sakit, ijin kepentingan lain, bolos sekolah, hal tersebut berdasarkan pengamatan penulis, catatan konselig di BK, pengamatan dari guru teman sejawat, laporan guru mapel, laporan wali kelas dan rekap absensi siswa, khususnya di kelas VIIIA. Ketidak disipilan siswa di kelas mayoritas disebabkan siswa yang sekolah di SMP N 1 Talang berasal dari keluarga broken home/ orang tua cerai, kurang perhatian orang tua, orang tua sibuk, banyak juga orang tua yang kerja diluar kota/ luar negeri, jarak tempuh dari rumah kesekolah jauh.

Hal ini tidak dapat dibiarkan begitu saja karena akan mempengaruhi siswa yang lain yang selalu hadir/ disiplin di kelas. Peran guru bimbingan dan konseling dalam mengatasi ketidakdisiplinan siswa tersebut dengan melakukan layanan konseling kelompok. Konseling 
kelompok menurut Kurnanto (2013) adalah Konseling yang terdiri dari 4-8 konseli yang bertemu dengan 1-2 konselor. Dalam prosesnya, konseling kelompok dapat membicarakan beberapa masalah, seperti kemampuan dalam membangun hubungan dan komunikasi, pengembangan harga diri, dan keterampilan-keterampilan dalam mengatasi masalah.

Pengertian dari Kurnanto tadi, sejalan dengan pendapat dari Nurihsan (2010) yang mengatakan bahwa konseling kelompok adalah suatu bantuan kepada individu dalam situasi kelompok yang bersifat pencegahan dan penyembuhan, serta diarahkan pada pemberian kemudahan dalam perkembangan dan pertumbuhannya. Menggunakan layanan konseling kelompok, maka siswa yang mengalami suatu masalah akan dibantu bersama-sama dengan anggota kelompok yang lain agar siswa tersebut mampu untuk mengatasi masalah yang sedang dia alami, sehingga nantinya siswa tersebut akan mampu untuk mandiri saat menghadapi masalah yang sama pada masa yang akan datang.

Tujuan penelitian yaitu Meningkatkan kedisiplinan masuk kelas pada siswa Kelas VIIIA SMP N 1 Talang Kabupaten Tegal Semester 2 Tahun Pelajaran 2019/2020 melalui layanan konseling kelompok dengan pendekatan behavioral, Mendiskripsikan langkah-langkah pelaksanaan layanan konseling kelompok dengan pendekatan behavioral dalam meningatkan kedisiplinan masuk kelas pada siswa Kelas VIIIA SMP N 1 Talang Kabupaten Tegal Semester 2 Tahun Pelajaran 2019/2020.

\section{METODE}

Jenis penelitian yang digunakan pada penelitian ini adalah penelitian tindakan bimbingan dan konseling (PTBK). Obyek dalam penelitian ini adalah kedisiplinan siswa masuk kelas yang akan ditingkatkan melalui layanan konseling kelompok dengan pendekatan behavioral dengan jumlah siswa sebagai subyek penelitian sebanyak 32 siswa, laki-laki 14 orang dan perempuan 18 orang, sebagai subyek penelitian yaitu siswa yang datang terlambat, bolos dan alpa di kelas VIIIA SMP N 1 Talang Kabupaten Tegal Semester 2 Tahun Pelajaran 2019/2020.Penelitian ini dilaksanakan di SMP Negeri 1 Talang Kabupaten Tegal, yang berlokasi di jalan Raya Projosumarto II No. 11 Talang. Penelitian dilakukan oleh guru BK sebagai peneliti dan dibantu dengan guru BK yang lain sebagai observer. Penelitian ini dilaksanakan enam bulan yaitu mulai bulan Januari sampai dengan bulan Juni Tahun Pelajaran 2019/2020. Teknik analisis data menggunakan teknik deskriptif komparatif.

\section{HASIL}

Penelitian ini adalah penelitian tindakan bimbingan yang dilakukan sebanyak 2 siklus dengan berkolaborasi dengan teman sejawat khususnya kolaborasi pada siklus berlangsung untuk membantu melaksanakan pengamatan secara bersama-sama, di mana tiap siklus terdiri dari empat tahap yaitu; Perencanaan, Pelaksanaan, Pengamatan dan Refleksi. Apabila siklus pertama belum berhasil maka dilanjutkan siklus kedua dan seterusnya.

\section{Prasiklus}

Subyek penelitian ini adalah siswa kelas VIIIA SMP Negeri 1 Talang semester 2 tahun Pelajaran 2019/2020 yang sering terlambat, bolos dan alpa. Alasan memilih kelas VIIIA sebagai subyek penelitian karena tingkat kedisiplinan masuk kelas pada siswa kelas tersebut rendah. Hal ini didasarkan oleh hasil pengamatan, rekap absensi, laporan dari wali kelas, guru mapel, catatan guru piket, dan catatan teman sejawat bahwa anak-anak pada kelas tersebut sering datang terlambat, bolos, dan alpa. Karena yang menjadi sasaran subjek penelitian ini kelas VIIIA maka pelaksanaan tindakan dilakukan di kelas tersebut yaitu kelas VIIIA. Karena Guru BK tidak punya jam masuk kelas secara terjadwal, maka 
penelitian ini dilaksanakan diluar jam pelajaran atau minta waktu pada guru mapel. Penelitian ini adalah penelitian tindakan bimbingan konseling yang direncanakan 2 siklus.

\section{Deskripsi Siklus 1}

Pada siklus 1 dilaksanakan pada Minggu ke 1 dan 2 tanggal 3 dan 11 Februari 2020 dengan langkah-langkah sebagai berikut:

\section{a. Perencanaan (Planning)}

Adapun tindakan dalam kegiatan perencanaan tindakan ini sebagai berikut:

1) Mendata siswa yang terlambat berdasarkan rekap absensi semester 2 dan bulan Januari Minggu ke 1- 4 khususnya kelas VIIIA.

2) Menyiapkan Rencana Pelaksanaan Layanan Konseling kelompok (RPL).

3) Menyiapkan data-data / rekapan tentang keterlambatan siswa.

4) Menyiapkan blangko observasi yang akan digunakan untuk mengamati siswa pada saat berlangsungnya kegiatan Konseling kelompok.

5) Menyiapkan blangko hasil kegiatan Konseling kelompok untuk siswa yang digunakan oleh siswa untuk mencatat kesimpulan-kesimpulan dari pelaksanaan Konseling kelompok.

\section{b. Pelaksanaan (Action)}

Berdasarkan data dari hasil rekapan yang diperoleh dari catatan guru $\mathrm{BK}$, absensi siswa, ternyata siswa kelas VIIIA bulan Januari sampai Minggu ke-4 dari jumlah seluruh siswa kelas VIIIA yang datang terlambat 13 siswa ( $40.63 \%$ ), yang bolos 6 siswa $(18,75 \%)$, alpa 10 siswa $(31,25 \%)$. Peneliti melaksanakan tindakan dengan melalui Konseling kelompok dengan menggunakan pendekatan behavioral dan dilaksanakan pada bulan Februari minggu ke 1 dan 2, adapun bentuk dari layanan Konseling kelompok sebagai berikut :

\section{Pertemuan I}

\section{1) Tahap Pembentukan}

a) Pemimpin kelompok mengungkapkan pengertian dan tujuan kegiatan kelompok dalam rangka pelayanan Konseling kelompok.

b) Pemimpin kelompok menjelaskan azas-azas kegiatan Konseling kelompok.

c) Anggota saling memperkenalkan diri.

d) Melakukan permainan, berupa nyayi bersama anggota kelompok

\section{2) Tahap Peralihan}

a) Pemimpin kelompok menjelaskan kegiatan yang akan ditempuh pada tahap berikutnya.

b) Pemimpin kelompok menawarkan sambil mengamati apakah para anggota sudah siap menjalani kegiatan tahap selanjutnya.

\section{3) Tahap Kegiatan}

a) Pemimpin kelompok memimpin kelompok untuk mengemukakan topik yang dibahas yaitu "Kedisiplinan siswa masuk kelas / sekolah.

b) Pemimpin kelompok menjelaskan teknik yang akan digunakan dalam kegiatan Konseling kelompok ini yaitu, curah pendapat, tanya jawab.

c) Pemimpin kelompok berharap agar para anggota kelompok bisa membahas materi yang disampaikan oleh pemimpin kelompok pada pertemuan ke dua nanti.

\section{4) Tahap Pengakhiran}

a) Pemimpin kelompok mengatakan kegiatan akan segera di akhiri.

b) Pemimpin kelompok dan anggota kelompok mengemukakan kesan dan hasil kegiatan.

c) Membahas kegiatan lanjutan/pertemuan selanjutnya.

d) Anggota kelompok mengemukakan kesan, pesan, dan harapan.

e) Pemimpin kelompok menyampaikan terima kasih dan salam penutup (salam BK).

\section{Pertemuan ke II}

1) Tahap pembentukan

a) Pemimpin kelompok mengingatkan kembali pengertian dan tujuan Konseling kelompok 
b) Pemimpin kelompok mengingatkan kembali azas-azas kegiatan Konseling kelompok.

\section{2) Tahap peralihan}

a) Pemimpin kelompok menjelaskan kegiatan yang akan ditempuh pada tahap berikutnya.

b) Pemimpin kelompok menawarkan sambil mengamati apakah para anggota sudah siap menjalani kegiatan pada tahap selanjutnya (tahap ketiga).

c) Pemimpin kelompok membahas suasana yang terjadi.

d) Pemimpin kelompok mengingatkan kemampuan keikutsertaan anggota.

\section{3) Tahap pelaksanaan/ kegiatan}

a) Pemimpin kelompok memimpin kelompok untuk mengemukakan topik yang dibahas yaitu" kiat-kiat agar datang ke sekolah tidak terlambat, tdak bolos, tidak sering alpa.

b) Tanya jawab antar anggota kelompok dan pemimpin kelompok hal-hal yang belum jelas tentang materi yang telah diberikan oleh pemimpin kelompok.

c) Anggota kelompok membahas materi yang yang telah diberikan oleh pemimpin kelompok secara mendalam dan tuntas.

d) Permainan selingan.

\section{4) Tahap pengakhiran}

a) Pemimpin kelompok mengemukakan bahwa kegiatan akan segera di akhiri.

b) Pemimpin kelompok dan anggauta kelompok mengemukakan kesan dan hasilhasil kegiatan.

c) Membahas kegiatan lanjutan/ pertemuan selanjutnya.

d) Anggota kelompok mengemukakan kesan, pesan, dan harapan

e) Pemimpin kelompok mengucapkan terimakasih dan salam.

\section{c. Pengamatan (Obsevation)}

Hasil pengamatan pada siklus 1 yang dilaksanakan pada bulan Februari Minggu ke 12 Tahun 2020 menunjukan bahwa dari $13(40,63 \%)$ siswa yang terlambat turun menjadi 6 $(18,75 \%)$, siswa yang bolos dari $6(18,75 \%)$ siswa turun menjadi 3 siswa $(9,36 \%)$, dan yang alpa 10 siswa $(31,25 \%)$ turun menjadi 6 siswa $(18,75 \%)$ setelah mendapatkan Konseling kelompok ada beberapa siswa yang masih terlambat masuk kelas.

\section{d. Refleksi}

Melihat dari data kondisi awal dan setelah diberikan tindakan Konseling kelompok ( siklus 1 ) dengan Konseling kelompok besar, terjadi peningkatan kedisiplinan siswa tetapi belum cukup signifikan. Untuk itu maka perlu ditindaklanjuti dengan mengadakan siklus 2 , agar peningkatan kedisiplinan siswa masuk kelas/sekolah bisa meningkat secara optimal.

Karena melihat data pada siklus I, masih ada siswa yang terlambat datang kesekolah, bolos dan alpa maka perlu adanya tindakan Konseling kelompok pada siklus 2 dilaksanakan bulan Maret Minggu ke 1- 2 pada tanggal 2 dan 10 Maret 2020 , supaya dapat meningkatkan kedisiplinan siswa lebih maksimal datang ke sekolah tepat waktu, tidak bolos dan alpa, adapun kegiatan-kegiatan pada siklus 2 meliputi:

\section{1) Perencanaan (Planning)}

Perencanaan tindakan pada siklus 2 ini hampir sama dengan siklus 1 namun ada perbedaan, yaitu pada pendataan siswa-siswa yang masih terlambat setelah siklus 1 , untuk mengetahui tingkat perkembanganya, adapun langkah-langkah untuk tindakan perencanaan sebagai berikut:

a) Mendata siswa-siswa yang masih terlambat. bolos dan alpa setelah diadakan siklus 1 .

b) Menyiapkan satuan layanan Konseling kelompok.

c) Menyiapkan data-data/rekapan-rekapan tentang keterlambatan, bolos, alpa pada siswa .

d) Menyiapkan blangko observasi yang akan digunakan untuk mengamati siswa pada saat berlangsungnya kegiatan Konseling kelompok. 
e) Menyiapkan blangko hasil kegiatan Konseling kelompok untuk siswa yang digunakan untuk mencatat kesimpulan-kesimpulan dari pelaksanaan Konseling kelompok.

2) Pelaksanaan (Action)

Pelaksanaan tindakan pada dasarnya sama dengan pelaksanaan tindakan pada siklus 1 hanya saja ada penambahan tindakan perbaikan dari kekurangan-kekurangan yang terjadi pada siklus 1 , penambahan tindakan perbaikan tersebut yaitu pada tahap pelaksanaan siswa diberikan tugas untuk mencatat perilaku mal-adaptif ke perilaku adaptif beserta solusinya kemudian didiskusikan bersama-sama dalam Konseling kelompok.

Adapun langkah-langkah dalam kegiatan Konseling kelompok pada siklus 2 adalah sebagai berikut:

\section{Pertemuan I}

\section{1) Tahap Pembentukan}

a) Pemimpin kelompok mengingatkan kembali asas-asas kegiatan Konseling kelompok.

b) Pemimpin kelompok mengingatkan kembali kesimpulan dari hasil pertemuan pada siklus 1

c) Melakukan permainan.

\section{2) Tahap peralihan}

a) Pemimpin kelompok menjelaskan kegiatan yang akan ditempuh pada tahap berikutnya.

b) Pemimpin kelompok menawarkan sambil mengamati apakah para anggota kelompok sudah siap menjalani kegiatan pada tahap selanjutnya (Tahap Ketiga).

c) Pemimpin kelompok membahas suasana yang terjadi.

d) Pemimpin kelompok meningkatkan kemampuan keikutsertaan anggota kelompok.

\section{3) Tahap pelaksanaan / Kegiatan}

a) Kelompok memimpin kelompok untuk mengemukakan topik yang dibahas yaitu "Kiat- kiat datang tepat waktu dan tugas membuat catatan perilaku mal- adaftip ke perilaku adaftip beserta solusinya".

b) Pemimpin kelompok memberi tugas kepada anggota kelompok supaya masingmasing dapat membuat catatan perilaku mal adaftip ke perilaku adaftip beserta solusinya..

c) Pemimpin kelompok berharap agar para anggota kelompok bisa membahas tugas yang diberikan oleh pemimpin kelompok.

\section{4) Tahap Pengakhiran}

a) Pemimpin kelompok mengemukakan bahwa kegiatan akan segera diakhiri.

b) Pemimpin kelompok dan anggota kelompok mengemukakan kesan dan hasilhasil kegiatan.

c) Membahas kegiatan lanjutan/ pertemuan selanjutnya.

d) Anggota kelompok mengemukakan kesan, pesan dan harapan

e) Pemimpin kelompok menyampaikan ucapan terima kasih dan salam penutup

\section{Pertemuan ke II}

Pada pertemuan ke dua ini sudah tidak ada pembahasan materi yang mendalam, hanya pengulasan secara singkat saja dan penyampaian kesan, pesan dan harapan oleh pemimpin kelompok, karena dari hasil pertemuan pertama siklus dua sudah nampak hasilnya yaitu siswa sudah tidak terlambat lagi mencapai $85 \%$, tetapi untuk langkahlangkah Konseling kelompoknya sebagai berikut:

1) Tahap pembentukan

Pemimpin kelompok mengingatkan kembali tentang hasil Konseling kelompok pada pertemuan

2) Tahap peralihan

a) Pemimpin kelompok menjelaskan kegiatan yang akan ditempuh pada tahap berikutnya. 
b) Pemimpin kelompok menawarkan sambil mengamati apakah para anggota sudah siap menjalani kegiatan pada tahap selanjutnya ( Tahap Ketiga)

c) Pemimpin kelompok membahas suasana yang terjadi.

d) Pemimpin kelompok meningkatkan kemampuan keikutsertaan anggota

3) Tahap pelaksanaan/ kegiatan

a) Pemimpin kelompok menyampaikan kesimpulan dan kesan dari topik-topik yang telah dibahas dari pertemuan yang telah lalu.

b) Pemimpin kelompok berharap agar para anggota kelompok bisa menerapkan perilaku yang adaftip yang telah dibuatnya sehingga akan lebih meningkatkan kedisiplinan di sekolah / kelas.

4) Tahap pengakhiran

a) Pemimpin kelompok mengemukakan bahwa kegiatan akan segera diakhiri.

b) Pemimpin kelompok dan anggota kelompok mengemukakan kesan dan hasilhasil kegiatan.

c) Anggota kelompok menyampaikan kesan, pesan dan harapan

d) Pemimpin kelompok menyampaikan ucapan terima kasih dan salam penutup.

5) Pengamatan (Observation)

Hasil pengamatan pada siklus 2 yang dilakukan oleh kolaborator terhadap peneliti bulan Maret minggu ke 1 -2 Tahun 2020 menunjukan suatu keberhasilan pada layanan Konseling kelompok dengan teknik konseling behavioral pada siklus 2.

6) Refleksi

\section{PEMBAHASAN}

Dari hasil penelitian tindakan bimbingan konseling yang sudah diuraikan diatas dapat dijelaskan bahwa masa pra tindakan pada bulan januari Minggu ke 2 - 3, jumlah 32 siswa dari berbagai variasi ketidak disiplinan masuk kelas/ sekolah baik itu terlambat, bolos dan alpa, pada kondisi awal terlambat 13 siswa (40,63\%) turun $(21,88 \%)$ menjadi 6 siswa $(18,75 \%)$, bolos 6 siswa $(18,75 \%)$ turun $(9,36 \%)$ menjadi 3 siswa $(9,36 \%)$, alpa 10 siswa $(31,25 \%)$ turun $(12,5 \%)$ menjadi 6 siswa $(18,75 \%)$, pada siklus 1 , tetapi setelah diberi tindakan pada siklus 2 terjadi peningkatan yang signifikan kedisiplinan masuk kelas pada kondisi awal siswa terlambat 13 siswa $(40,63 \%)$ turun $31,37 \%$ pada akhir siklus menjadi 3 siswa (9,36\%), siswa bolos dari 6 siswa $(18,75 \%)$ turun 18,75 $\%$ menjadi 0 siswa (0\%), sedangkan siswa yang alpa pada kondisi awal ada 10 siswa $(31,25 \%)$ turun $25 \%$ menjadi 2 siswa $(6,25 \%)$.

Hal ini dikarenakan setelah siswa diberikan layanan Konseling kelompok dengan pendekatan behavioral menjadi lebih bisa terbuka dalam neyampaikan pendapat dan sharing dengan anggota kelompok, dan diantara teman anggota kelompok tersebut ada yang bisa memberikan gagasan positif sehingga anggota lain yang tadinya tidak disiplin / kurang disiplin lebih dapat menerima masukan dari teman atau anggota kelompok yang akhirnya lebih bisa berubah untuk lebih meningkatkan kedisiplinannya dan diberikan apresiasi oleh pimpinan kelompok berupa pujian bagi siswa yang sudah tidak pernah terlambat, bolos, dan alpa. Sedangkan pada ketiga siswa dengan kode 018, 020, 026 yang masih kurang disiplin diberikan tindakan layanan konseling individual dan pemanggilan orang tua.

\section{SIMPULAN}

Layanan konseling kelompok dengan pendekatan behavioral dapat meningkatkan kedisiplinan siswa masuk kelas pada siswa Kelas VIIIA SMP N 1 Talang Kabupaten tegal semester 2, tahun pelajaran 2019/2020 hal ini dapat dilihat dali nilai meningkatnya kedisiplinan peserta didik dari pra siklus, siklus 1 dan siklus II. 


\section{SARAN}

Saran-saran yang dapat peneliti sampaikan dalam penelitian ini sebagai berikut: 1) Siswa hendaknya selalu meningkatkan kedisiplinan masuk kelas/sekolah tepat waktu dengan cara berangkat sekolah sebelum jam tujuh siswa sudah sampai sekolah, tidak bolos dan tidak sering alpa, mematuhi tata tertib yang ada disekolah sehingga tercipta lingkungan belajar yang kondusif dan dapat mencapai kompetensi yang diharapkan, 2) Guru BK seyogyanya menerapkan model layanan Konseling kelompok dengan pendekatan behavioral dalam menangani siswa yang tidak disiplin masuk kelas / sekolah, terlambat, bolos dan alpa dengan menggunakan kelompok kecil ( 5-12 siswa ) agar bimbingan lebih efektif.

\section{DAFTAR PUSTAKA}

Loso. 2007. Budi Pekerti Jilid 1. Jakarta: CV. Sinar Cemerlang Abadi.

Setiawan, Conny. 2009. Penerapan Pembelajaran Bagi Anak. Bandung: Pt Indeks.

Kurnanto, M. Edi. 2013. Konseling Kelompok. Bandung: Alfabeta.

Nurihsan, Achmad Juntika. 2010. Strategi Layanan Bimbingan dan Konseling. Bandung: PT Refrika Aditama

Rintiyastini, Yulia \& Suzy Charlote, Yulia S. 2006. Bimbingan Konseling 2 SMP. Jakarta: PT. Gelora Pratama. 